Volume-V,Issue-02, July-December, 2010

\title{
Quality of Categorized Service and Customer Satisfaction in Banking Industry: An Empirical Study on Private Commercial Banks in Bangladesh
}

\author{
MD. MASUKUJJAMAN ${ }^{1}$ \\ AFIA AKTER $^{2}$
}

\begin{abstract}
The main objectives of the study are to evaluate the customer satisfaction of the service quality and to assess whether bank services provided by the institutions are satisfactory to Bangladeshi customers especially in term of service categories like general banking, credit banking and foreign exchange banking services. The study also examines empirically the determinants of service quality in Bangladesh. A questionnaire for such purpose was designed and different statistical methods were applied to analyse the collected data. From the study it is found that the overall service quality in private commercial bank in Bangladesh is moderate, where service quality in general banking services is better than the credit banking services and foreign exchange services though its quality is not too bad. In addition, top ranked banks have high service quality in all categories of services and the lower raked banks are struggling seriously with credit and foreign exchange services. So, as policy recommendation, the banks especially the lower ranked banks should give more emphasis on both the credit and foreign exchange banking services.
\end{abstract}

Key Words: Categorized Service, Perceived Service Quality, Customer Satisfaction.

\section{INTRODUCTION}

The health and efficiency of the financial sector are crucial to economic growth of a country because the pace of economic growth, a balanced capital market, an efficient flow of fund between savers and investors cannot be sustained without a sound financial sector. Financial sector of Bangladesh, like most low-income countries, is dominated by the banking enterprises. As a result, the performance of

1 Lecturer in Finance, Department of Business Administration, Northern University Bangladesh. E-mail: masuk_iba111@yahoo.com.

2 Senior Lecturer in Finance, Department of Business Administration, Northern University Bangladesh. E-mail: afia_t@yahoo.com. 
the banking sector has a direct correlation with the entire financial sector and economy of our country. In every country, the banking sector is the most important mechanism for performing a lot of tasks related to deposit mobilization, credit evaluation and monitoring, providing access to a payments system and to a clearinghouse for transactions. It is the system by which a country's most profitable and efficient projects are systematically and continuously funded, and thus it is the mechanism, which ensures that resources are directed to the most productive sources of the future growth. The system not only transfers funds from savers to investors, it must be able to select projects which will yield the highest returns, accumulate sufficient amount of capital to fund the range of investment projects across economic activities, account for price risks across assets, monitor performance, and enforce contracts.

Therefore, in a country like Bangladesh, characterized by low savings rate, a large non- monetized sector, lack of institutions to tap rural savings, the paramount importance of banking is well recognized. As banks play the most significant role in the economy, it is important to evaluate the performance of banks (Farzana and Zariab, 2008). Other than the financial performance, maintaining customer satisfaction could be an efficiency indicator of banks.

Today, banking is also seen as a business related to information on financial transactions, since Information Technology (IT) has been pivotal to effective customer service at lower costs. For example, IT-based services such as automated teller machines (ATM), electronic fund transfer, anywhere-anytime banking, smart cards, net banking, etc. are now very common to Bangladeshi customers. The private commercial banks do already have the advantage of good automation experience in several banking applications, yet their transactions are confined to a few major cities in Bangladesh that is also creating competitive environment among the banks. In this competitive and ever changing environment, banks can ensure their survival and gain a competitive edge through the emphasis on using service quality as a means of differentiation (Khalid, et al., 2000)

Over the past few years there has been a heightened emphasis on service quality and customer satisfaction in business and academia alike. (Muzahid and Noorjahan, 2009) The subject of continued (and considerable) debate in the marketing literature, the distinction and association between service quality and customer satisfaction remains at the forefront of many academic- and practitioner-oriented research endeavors ( Spreng and Mackoy,1995). There exist numerous empirical works to support the quality/satisfaction causal order. In a study, Cronin and Taylor (1992) tested, among other things, the casual relationship between service quality and customer satisfaction. Their study emphasized that marketing researchers are not in agreement in terms of the causal order of these constructs, and suggested that 
empirical justification is necessary to determine the true nature of this relationship. The findings of this study revealed that perceived service quality leads to satisfaction (as opposed to the reverse) (Cronin and Taylor, 1992).

In other study addressing the relationship between service quality and satisfaction, Spreng and Mackoy (1996) suggested that perceived service quality was an antecedent to satisfaction. Although the direction of the quality/satisfaction relationship (i.e. quality leads to satisfaction) is fairly well understood for services, the question of whether or not (and how) this relationship varies depending on particular settings and/or situations is not ${ }^{\mathrm{i}}$ (Spreng and Mackoy, 1995). Service quality and customer satisfaction do exhibit independence and are indeed different constructs from the customer's point of view. A small step in unearthing and understanding the constructs of service quality and customer satisfaction and their implications on competitive fruition has been put forward in a study conducted by Sureshchandar, Chandrasekharan and Anantharaman (2002), on banking services. Some researchers also claimed that perception of either positive or negative service quality was related to the customer's future behavioral intentions (Dash and Satish, 2007)

In a recent study Masum and Ashiqurrahman (2008) have found that Human Resource Management has significant effects on customer satisfaction level in the banking industry of Bangladesh.

\section{Rationale of the Study}

From the customers' perspective, service quality significantly influences customer satisfaction and customer satisfaction has direct influences on loyalty. Research findings indicate that service quality influences purchase intentions more than does customer satisfaction. It is therefore imperative on the part of bankers to stress upon both service quality and customer satisfaction, in order to raise the retention intentions of customers. Also, no research has so far been conducted in Bangladesh on customer satisfaction based on categories of services among banks. The empirical results of the present study may therefore provide improved insights on banking service filling the prevailing research gaps and it seeks to simultaneously analyze service quality and customer satisfaction.

\section{Objectives of the Study}

The focus of the study is to find out the relationship between service quality and customer satisfaction among the various private commercial banks. 
The specific objectives are:

(i) To identify the perceived service quality by the customers of the banks with regard to the General, Credit and Foreign Exchange services provided by the selected branches of the private commercial banks.

(ii) To differentiate the best service categories based on service quality among the cited banks of private commercial banks.

(iii) To rank the determinants of service quality and understanding satisfaction level of the customers.

(iv) To ascertain the other relevant dimensions of customer satisfaction.

(v) To offer suggestions, if needed, based on the analytical results of the current study.

Keeping in view the above objectives, the present study seeks to test the hypothesis as follows:

H1: The impact of General Banking service quality on customer satisfaction is significant.

H2: The impact of Credit Banking service quality on customer satisfaction is significant.

H3: The impact of Foreign Exchange service quality on customer satisfaction is significant.

\section{Limitations of the study}

- One of the limitations of this study is that only the interest based (traditional) commercial banks are considered for inferring the decision. The findings could be more representative if profit based (Islamic Sariah based) commercial banks and foreign commercial banks were included in the future comparative research.

- The survey was conducted on the private commercial banks based in Dhaka city. So, country wide survey could provide more representative findings.

\section{RESEARCH METHODOLOGY}

For fulfilling the research objectives primary source was used. Interview technique was used with structured questionnaire for the collection of primary data. The judgmental sampling procedure was used to select the sample units from different customers of different commercial banks who were willing to respond to the questionnaire. All the Bangladeshi private commercial banks were taken as the population of the study and 480 customers are taken as the sample of the survey. As 
the sample banks, sixteen (16) banks have been selected among the local private commercial banks in Bangladesh. The survey was administerd in 2008-2009.

SPSS version 15.0 was used to tabulate and analyze the valid responses. Few statistical tools such as Mean, Standard Deviation, Person's Correlation, ANOVA, T-test, and F-test were used for the analysis. Mean is arithmetic average and standard deviation is measure of dispersion or variation (Fallik and Brown, 1983). Person's correlation shows a relation that exists between two or more variables (Wolff and Pant, 2003). Analysis of variance (ANOVA) is a procedure used for comparing sample means to see if there is significant evidence to infer that the means of the corresponding populations' distribution also differs (Darren, and Mallery, 2006).

\section{CONCEPTUAL FRAMEWORK}

\section{Service Category}

The level of banking services can be divided into three major categorizes like General Banking, Credit and Foreign Exchange. The general banking functions include accounts opening, deposit management, cash handling etc. Whereas, the credit banking service deals with the loan disbursement and loan management and the foreign exchange banking covers the area of L/C function, foreign currency and remittance management. Foreign exchange banking services is a modern service compare to the general and credit banking services for each of the bank in Bangladesh.

\section{Service Quality}

In this study perceived service quality -the consumer's judgment about an entity's overall experience or superiority (Zeithaml, 1987)-is interchangeably meant in lieu of service quality. Traditionally, service quality has been conceptualized as the difference between customer expectations regarding a service to be received and perceptions of the service being received (Zeithaml and Berry, 1988). In some earlier studies, service quality has been referred as the extent to which a service meets customers' needs or expectations (Lewis and Mitchell, 1990). It is also conceptualized as the consumer's overall impression of the relative inferiority or superiority of the services (Zeithaml and Berry, 1990). So, service quality is a relativistic and cognitive discrepancy between experience-based norms and performances concerning service benefits (Roest and Pieters, 1997). 


\section{Customer Satisfaction}

Satisfaction as a state felt by a person who has experienced performance or an outcome that fulfill his or her expectation. It is a function of relative level of expectations and perceived performance (Kotler and Clarke, 1987). In another way, satisfaction is a positive, affective state resulting from the appraisal of all aspects of a party's working relationship with another (Boeselie and Wiele, 2002). While customer satisfaction is an individual's feeling of pleasure or disappointment resulting from comparing a product's perceived performance (or outcome) in relation to his or her expectations (Brady and Robertson, 2001).

Figure 1: A model of customer satisfaction.

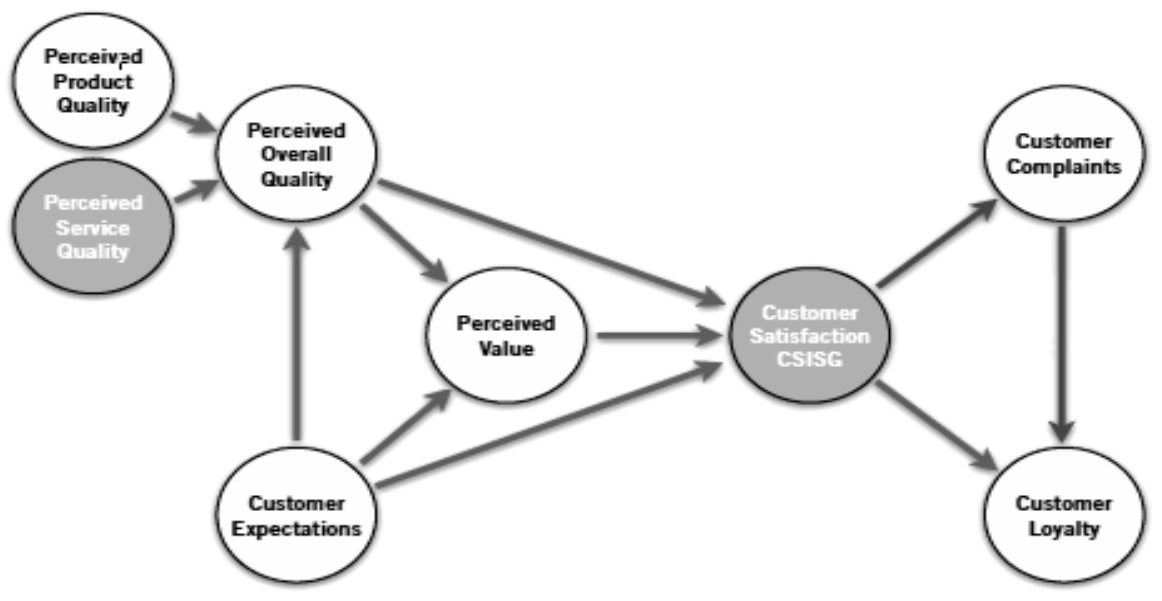

Source: The Customer Satisfaction Index of Singapore, Singapore Management University, ( Marcus, 2009)

Customer satisfaction is a well known and established concept in several areas like marketing, economic psychology, welfare-economics, and economics (Muzahid and Noorjahan, 2009). Customer satisfaction is not the final destination of any service. It has a positive correlation between customer satisfaction and loyalty (Anderson and Sullivan, 1993).

\section{Customer Loyalty}

Customer loyalty is the mindset of the customers who hold favorable attitudes toward a company, commit to repurchase the company's product/service, and 
recommend the product/service to others (Pearson, 1996). It expresses an intended behavior related to the product or service or to the company. Customer satisfaction performs an important mediating role between service quality and customer loyalty (Muzahid and Noorjahan 2009).

\section{The Distinction between Service Quality and Customer Satisfaction}

A review of the emerging literature suggests that there appears to be relative consensus among marketing researchers that service quality and customer satisfaction are separate constructs which is unique and share a close relationship (Oliver, 1993). Many studies of consumer satisfaction have been conducted in service settings, and, generally, researchers agree that the two constructs are conceptually distinct (Bitner, 1990). Table-1 identifies a number of key elements that distinguish customer satisfaction from service quality.

TABLE 1

\section{THE DISTINCTION BETWEEN CUSTOMER SATISFACTIONS}

\section{AND SERVICE QUALITY}

\begin{tabular}{|l|ll|}
\hline \multicolumn{1}{|c|}{ Customer Satisfaction } & \multicolumn{1}{|c|}{ Service Quality } \\
\hline $\begin{array}{l}\text { Customer satisfaction can result from any } \\
\text { dimension, whether or not it is quality } \\
\text { related. }\end{array}$ & $\begin{array}{l}\text { The dimensions underlying quality } \\
\text { judgements are rather specific. }\end{array}$ \\
\hline $\begin{array}{l}\text { Customer satisfaction judgments can be } \\
\text { formed by a large number of non-quality } \\
\text { issues, such as needs, equity, perceptions } \\
\text { of fairness. }\end{array}$ & $\begin{array}{l}\text { Expectations for quality are based on ideals } \\
\text { or perceptions of excellence. }\end{array}$ \\
\hline $\begin{array}{l}\text { Customer satisfaction is believed to have } \\
\text { more conceptual antecedents. }\end{array}$ & $\begin{array}{l}\text { Service quality has less conceptual } \\
\text { antecedents. }\end{array}$ \\
\hline $\begin{array}{l}\text { Satisfaction judgments do require } \\
\text { experience with the service or provider. }\end{array}$ & $\begin{array}{l}\text { Quality perceptions do not require } \\
\text { experience with the service or provider. }\end{array}$ \\
\hline
\end{tabular}




\subsection{SPECIFICATION OF THE MODEL}

This section discusses the model specifications to examine the relationships between customer satisfaction and service quality using panel least squares estimation method.

The model is derived, in conventional manner, from a production function in which factors of perceived service quality is introduced as an input. In the usual notation the production function can be shown as follows:

$$
Y=f(\mathrm{G}, \mathrm{C}, \mathrm{F})
$$

where $\mathrm{Y}$ is the Customer Satisfaction, and G,C,F are the service quality of General banking, Credit Banking, and Foreign Exchange banking respectively.

Assuming (1) to be linear, the following expression, describing the determinants of the customer satisfaction, is obtained:

$$
Y=\beta o+\beta 1 \mathrm{G}+\beta 2 C+\beta 3 F+\mu e .
$$

where $\beta$ denotes coefficient of respective factor of the customer satisfaction and $\mu \mathrm{e}$ is the residual.

\subsection{AN EMPIRICAL INVESTIGATION}

For investigating customer's satisfactions in the banking sector of Bangladesh, and to derive policy implications a standard structured questionnaire was designed based on review of service quality and customer service literature to collect the required information where five point Likert type scale (where $1=$ "strongly agree," $2=$ Agree, 3 = "moderate", $4=$ "Disagree" and 5 = "Strongly Disagree.") and other demographic nominal information (gender, profession, marital status, salary, age and education, yearly income, number and types of account maintained) were presented. Also, both open ended and close ended formats were used based on the nature of the questions. The measure consists of three sets of questions. The set was related with general banking service, credit banking service, and foreign exchange service respectively.

\section{Respondents' profile}

The Table- 2 indicates that $83.8 \%$ of the respondents were male and $16.3 \%$ were female. Out of the total respondents $55 \%$ were between 20 and 29 years range, 29.4 $\%$ were between 30-39 years range and $14.4 \%$ respondents were over 40 and 43.8 $\%$ respondents were single. A large number of the respondents $(40 \%)$ were interestingly self employed. The Table also revealed that a significant number of respondents (66.3\%) were highly educated (University Graduates). 
A profile of respondents is presented in the following table:

TABLE-2

PERSONAL BACKGROUND OF RESPONDENTS

\begin{tabular}{|c|c|c|c|}
\hline$(\mathrm{N}=480)$ & & Frequency & Percentage $(\%)$ \\
\hline \multirow[t]{2}{*}{ Gender } & Male & 402 & 83.8 \\
\hline & Female & 78 & 16.3 \\
\hline \multirow[t]{5}{*}{ Age } & Under 20 & 4 & 0.8 \\
\hline & $20-29$ & 192 & 40 \\
\hline & $30-39$ & 189 & 39.4 \\
\hline & $40-49$ & 81 & 16.9 \\
\hline & $50+$ & 14 & 2.9 \\
\hline \multirow[t]{3}{*}{ Marital status } & Married & 312 & 65 \\
\hline & Single & 162 & 33.8 \\
\hline & Others & 6 & 1.3 \\
\hline \multirow[t]{4}{*}{ Education } & Primary & 3 & 0.6 \\
\hline & High School & 31 & 6.5 \\
\hline & College & 140 & 29.2 \\
\hline & University & 306 & 63.8 \\
\hline \multirow[t]{6}{*}{ Working Status } & House Wife & 14 & 2.9 \\
\hline & Self Employed & 234 & 48.8 \\
\hline & Civil servant & 74 & 15.4 \\
\hline & Wage Earner & 11 & 2.3 \\
\hline & Pensioner & 11 & 2.3 \\
\hline & Others & 136 & 28.3 \\
\hline
\end{tabular}

Source: Field survey, July-August, 2008 and May-June, 2009

\subsection{Measuring Perceived Service Quality of Banks}

It is found that the perception about overall service quality is about $71.49 \%$ regardless of the categories of services. About $78.06 \%$ of the respondents think that the performance is high in the general banking service, while, $69.71 \%$ and $66.72 \%$ reported that banks provide higher performance in Credit banking and foreign exchange banking service respectively (Figure-2). The reason could be the maturity of banking in providing general banking services comparative to the relatively modern services like foreign exchange services. 
Figure-2: Perceived Service Quality of the Private Commercial Banks

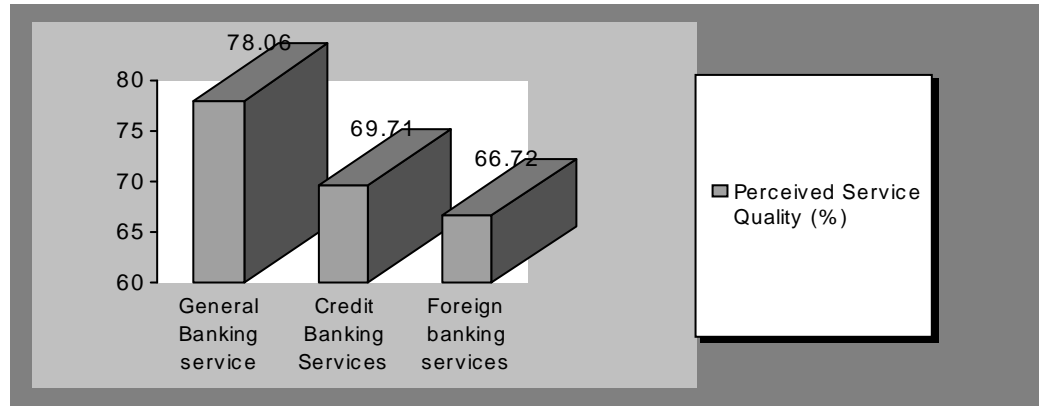

Source: Field survey, 2008-2009

Individual performance in respect of the qualitative services provided by the banks indicates (Table-3) that Dutch Bangla Bank Ltd. (86.5\%) has majority of support by the respondents which is followed by Brac Bank Ltd (81\%), Jamuna Bank Ltd. (77.5\%), Dhaka Bank Ltd.(79\%), and Eastern Bank Ltd. (76.5\%), while least support is $55 \%$ by the Bangladesh Commerce Bank Ltd.

TABLE-3

STATISTICAL FINDINGS

\begin{tabular}{l|c|c|c|c}
\hline \multirow{2}{*}{ Name of the Banks } & \multicolumn{4}{c}{ Perceived Service Quality (\%) } \\
\cline { 2 - 5 } & GB & CB & FX & Average \\
\hline National Bank limited & 81 & 69 & 75 & 75 \\
United Commercial Bank Limited & 70 & 40 & 70 & 69.5 \\
Arab Bangladesh Bank limited & 73 & 80.15 & 59.85 & 71 \\
National Credit and Commerce bank limited & 73 & 63 & 71 & 69 \\
Dhaka Bank Limited & 88 & 71 & 78 & 79 \\
Southeast Bank limited & 85 & 77 & 81 & 81 \\
Eastern Bank Ltd. & 90 & 59.5 & 80 & 76.5 \\
Bangladesh Commerce Bank Ltd. & 57 & 62 & 46 & 55 \\
Mercantile Bank ltd. & 82 & 73 & 67 & 74 \\
Mutual trust Bank ltd. & 65 & 53 & 68 & 62 \\
One Bank Limited & 59 & 80.25 & 49.75 & 63 \\
Standard Bank Limited & 78 & 56 & 40 & 58 \\
Premier Bank Limited & 77 & 68 & 56 & 67 \\
Jamuna Bank Limited & 90 & 70.5 & 72 & 77.5 \\
BRAC Bank limited & 88 & 90 & 65 & 81 \\
Dutch Bangla bank Limited & 92 & 86 & 80.5 & 86.5 \\
Average- & $78.06 \%$ & $69.71 \%$ & $66.72 \%$ & $71.49 \%$ \\
\hline
\end{tabular}

Source: Field survey, July-August, 2008 and May-, June, 2009 


\section{Determinants of Service quality}

General Banking Services

TABLE-4

STATISTICAL FINDINGS

\begin{tabular}{lclll}
\hline \multicolumn{1}{c|}{ Attributes } & Mean score & Standard Deviation & Rank \\
\hline Accounts opening is easy & 2.10 & .871 & 3 \\
Satisfactory interest on deposits & 2.56 & .824 & 4 \\
Quick customer service & 2.06 & .842 & 2 \\
ATM services are widely available & 3.19 & 1.349 & 7 \\
Efficient E-banking system & 2.68 & .1 .016 & 6 \\
All types of fees and charges are affordable & 2.62 & .875 & 5 \\
Sometimes banks fail to pay demanded & 1.38 & .691 & 1 \\
withdrawal* & & & \\
\hline
\end{tabular}

*Note: scale like $1=$ never faced, $2=$ sometimes faced, $3=$ always faced, $4=$ no comment is used.

Source: Field survey, July-August, 2008 and May- June, 2009

Among the different factors (Table-4), contributing service quality, it is evident from this survey that availability of ATM services (43.7\%), Efficiency in E-banking system $(30.1 \%)$ are seemed to be less weighted factors by the customer in general banking services. The given top prioritized factors are the non-failures of meeting withdrawal (94.4\%), Quick customer services (76.3\%), Easy in accounts opening procedure $(67.5 \%)$, Satisfactory interest on deposit (46.3), Cheaper Fees and Charges (51.3\%) accordingly.

\section{Credit Banking services}

Table-5 indicates that, the respondents give priority factors to like issuance of loan with security (82.9\%), time to issue loan (55.1\%). While, all types of present fees and charges to disbursement loan are high (55.9\%), Bank issue loan at a satisfactory interest rate $(38.1 \%)$ are the least contributing factors in deciding the service quality.

Respondent provide moderate emphasis on the factor such as easy loan collection procedure (60.5\%) and Flexible loan re-payment time (46.4\%) shaping their opinion about the service quality. 
TABLE-5

STATISTICAL FINDINGS

\begin{tabular}{l|c|c|c}
\hline \multicolumn{1}{c|}{ Attributes } & $\begin{array}{c}\text { Mean } \\
\text { score }\end{array}$ & $\begin{array}{c}\text { Standard } \\
\text { Deviation }\end{array}$ & Rank \\
\hline Loan collection procedure is very easy & 2.38 & .842 & 3 \\
Bank issue loan at a satisfactory interest rate & 2.86 & 1.012 & 6 \\
Bank issues loan with a security & 1.93 & .780 & 1 \\
The bank is Flexible for loan re-payment time & 2.51 & .848 & 4 \\
$\begin{array}{l}\text { All types of present fees and charges to } \\
\text { disbursement loan are high }\end{array}$ & 2.66 & .904 & 5 \\
Time used by bank to issue loan & 2.16 & .775 & 2 \\
\hline
\end{tabular}

*Note: scale like $1=$ =ery long, $2=$ long, $3=$ neither neither long nor short, $4=$ short, $5=$ very short is used.

Source: Field survey, July-August, 2008 and May- June, 2009

Foreign Exchange banking services

TABLE 6

STATISTICAL FINDINGS

\begin{tabular}{lccc}
\hline \multicolumn{1}{c}{ Attributes } & Mean score & $\begin{array}{c}\text { Standard } \\
\text { Deviation }\end{array}$ & Rank \\
\hline $\begin{array}{l}\text { The bank provide quick service in terms } \\
\text { of transferring funds }\end{array}$ & 2.15 & .879 & 1 \\
$\begin{array}{l}\text { Bank charges are modest in transferring } \\
\text { the funds }\end{array}$ & 2.69 & .841 & 3 \\
$\begin{array}{l}\text { LC Processing is very easy with the bank } \\
\begin{array}{l}\text { Satisfactory LC commission is charged } \\
\text { by the bank }\end{array}\end{array}$ & 2.56 & .825 & 2 \\
\hline
\end{tabular}

Source: Field survey, July-August, 2008 and May- June, 2009

Table-6 shows that the customers favor quick service in transferring funds (67.2\%) and easy LC processing (48\%) and give less emphasis on Bank charge in transferring fund (44.3\%) and LC commissions (32.7\%) when they are asked about the foreign exchange service quality. The reasoning could be drawn in this way that the customers are considering top ranked factors as moderately primary needs while lower ranked factors as secondary to coincide their overall service quality. 


\section{Overall Customer Satisfaction}

In order to find out the level of satisfaction towards the bank the respondents were asked to express their overall satisfaction on the basis of service quality dimensions mentioned earlier. The findings are reported in Figure 3.

Figure-3: Level of Satisfaction Towards the Banks

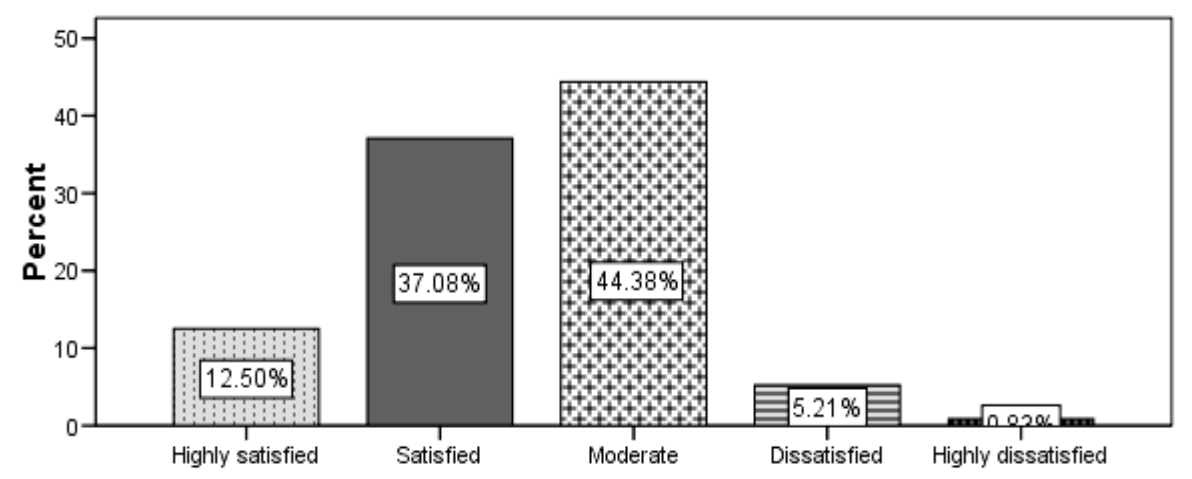

Source: Field Survey, 2008-2009.

It can be noted from the graph that a significant proportion of the respondents (49.58\%, out of which $12.5 \%$ articulated high satisfaction and $37.08 \%$ articulated satisfaction) expressed their satisfaction towards the bank considering the service quality. On the other hand, a considerable number of respondents $(44.38 \%)$ articulated moderate attitude towards the service. The graph also reveals that $5.21 \%$ expressed their dissatisfaction towards the bank service. Though insignificant portion of customers are dissatisfied, still they have some more desire to be satisfied indeed.

\section{Customer Satisfaction from Other Dimensions}

Other than the factors relevant to the classified services, the physical environment factors, customer relation factors etc have significant influence on the customer satisfaction.

\section{Customer relation and environment}

Figure-4 shows that majority of the respondents agree that employee behavior (78.3\%) to the customers and bank environment (72.9\%) is satisfactory. A insignificant portion of respondents expressed their dissatisfaction regarding 
customer relation and environment. About 58.5\% respondent agreed about the present layout while almost $34 \%$ respondents became moderate.

Figure-4: Opinion Regarding Work Layout, Bank Environment and Employee Behavior with Customer

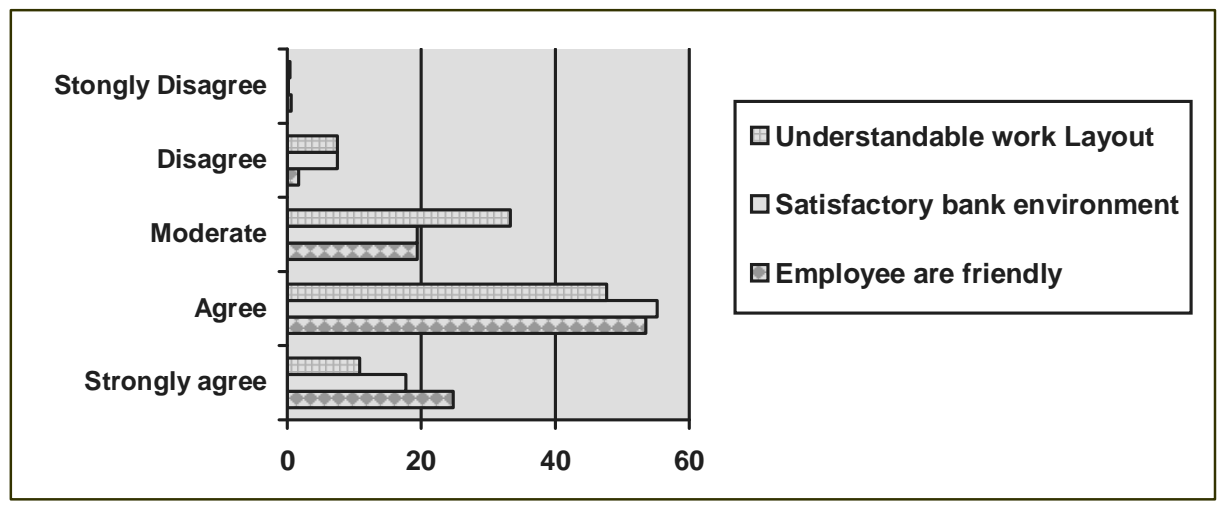

Source: Field survey, 2008-2009.

\section{Customers' future expectations}

From Fig-5, it is found that almost $87.23 \%$ of the respondents expect 24 hours banking whereas about $78.75 \%$ desire new types of deposit scheme which means that customer is eyeing more flexibility and facility in banking services.

Figure 5: Opinion Regarding New Deposit Scheme and 24 Hours Banking Services

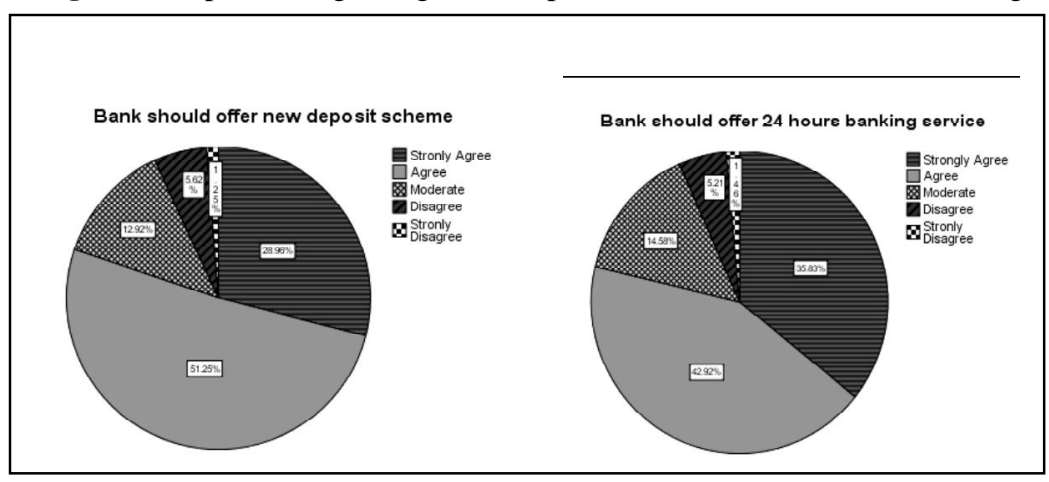

Source: Field survey, 2008-2009. 


\subsection{Relationship between quality of categorized Service and Customer Satisfaction}

$Y=-0.916+0.527 \mathrm{G}+0.631 \mathrm{C}+0.376 \mathrm{X}$

$\mathrm{t} \quad(13.745)^{*}(14.434)(10.499)$

* Significant at $5 \%$ level

From the calculation, it is found that the impact of General, credit and foreign exchange service quality on customer satisfaction is significant (Hypothesis: 1, 2, 3) at $5 \%$ level of significance which indicates that the quality of categories services affect the customer's satisfaction.

Based on the hypotheses $(1,2,3)$, Model shows that the effects of general service quality, credit service quality and foreign exchange service quality on customer satisfaction are significant $(\mathrm{R} 2 \mathrm{adj} .=0.610, \mathrm{~F} 3,367=193.73$ at $5 \%$ level of significance).[Appendix]

\section{SUMMARY}

\section{Findings and recommendations}

- The study showed that the overall service quality in private commercial bank in Bangladesh is considerable; still it is not sufficient for overwhelming satisfaction. To be more specific, the quality of perceived service in general banking services is better than the credit banking services and foreign exchange services, though their quality is not too bad.

The banks holding higher Perceived Service Quality are providing best service in all categories of banking service. Besides, the banks holding lower Perceived Service Quality are struggling seriously with credit and foreign exchange services. So, they should be more concerned about the quality of services of the two mentioned categories.

- The study reveals that customers are moderately satisfied with the bank services. Specifically, in general banking, customers are found satisfied with those banks who have less failure to meet the withdrawal, quick in customer services, easy accounts opening procedure. As well as in credit banking services, customers are satisfied with those banks which have a loan with security policy, taken lower time issuing loan, easy loan collection policy. While, quick in fund transferring facility, easy LC 
processing, lower charges in transferring fund were the factors in Foreign exchange services satisfying banks customer.

- Customers expect new types of deposit scheme, 24 hour banking services, security in banking transactions, mobile banking services, and ATM services with out any disruption in services. So, banks should introduce these desired services.

- The study is also found that other aspects of the customer satisfaction like the employee behavior to customer, the work environment and layout are satisfactory. So, they should maintain it to carry out their smooth performance.

- The study clearly shows that, there is a significant relationship between the quality of categories of services and the customers' satisfaction. So, banks should consider this correlation for their policy development and future progress.

\section{Conclusion}

Service quality has been widely accepted as an antecedent of satisfaction and neglecting it may jeopardize the competitiveness of an organization. For that, denying or neglecting the importance of service quality is the same like risking the continuation and the competitiveness of the institutions because by taking it into consideration service quality can explain variance in satisfaction. More than that, by focusing on critical factors in service quality means that the institution is paving a way toward an improved situation in customer satisfaction.

\section{REFERENCES}

Al-Sulaiti, Khalid, et al.( 2000 ). "Banking Service and Customer Satisfaction in Qatar: An Statistical Analysis", College of Business and Economics, Qatar University, P-131.

Akbar, Muzahid, Mohammad and Parvez Noorjahan (2009), "Impact of Service quality, Trust, and Customer Loyalty on Customer's Loyalty", ABAC Journal Vol. 29, No. 1, .24-38.

Anderson, E. \& Sullivan, M. (1993). "The Antecedents and Consequences of Customer Satisfaction for Firms". Marketing Science, 12 (1), 125-143.

Bitner, M. J. (1990). "Evaluating Service Encounters: The Effects of Physical Surroundings and Employee Responses", Journal of Marketing, 54(2), 69-82.

Billah, masum, M., and Ashiqurrahman, Sheikh. (2008). "HRM Practices and Customer Satisfaction Level: A Study on Private Commercial Banks in Bangladesh", Journal of 
Business and Technology, Northern University Bangladesh, (Dhaka), vol.3, No.6, JulyDecember, p-48.

Boeselie, P., Hesselink, M. \& Wiele, T.V. (2002). "Empirical Evidence for the Relationship Between Customer Satisfaction and Business Performance". Managing Service Quality, 12 (3), 184-193.

Brady, M. K., and Robertson, C. J. (2001). "Searching for A Consensus on the Antecedent Role of Service Quality and Satisfaction": An Exploratory Cross-national Study. Journal of Business Research, 51(1), 53-60.

Cronin, Jr., and Taylor, S. S. (1992), “An Investigation into the Determinants of Customer Satisfaction", Journal of Marketing Research, 19, 491.

Dash, M. K. and Satish Kumar (2007), "Measuring Customer Satisfaction in the Banking Industry with Special Reference to Service Quality Model, Effulgence, 5(2).

Fallik, F. \& Brown, B. L. (1983). "Statistics for Behavioral Sciences". Homewood: Dorsey Press.

Fen Sheau Yap et al.(2007), "Service Quality and Customer Satisfaction: Antecedents Of Customer's Re-Patronage Intentions", Sunway Academic journal-4 P-62: http://www.scribd.com/document_collections/2342533. (Access Date: 10/07/10, time: $10 \mathrm{pm})$.

George, Darren, and Mallery, Paul (2006). "SPSS for Windows Step by Steps: A Simple Guide and Reference". ed. $6^{\text {th, }}$ India: Pearson education Inc.p-144.

Kotler, P., \& Clarke, R. N. (1987). "Marketing for Health Care Organizations”. Englewood Cliffs, NJ: Prentice-Hall.

Lewis, B. R. \& Mitchell, V. W. (1990). "Defining and Measuring the Quality of Customer Service". Marketing Intelligence \& Planning, 8 (6), 11-17.

Lee, Marcus. (2009). "The customer Satisfaction Index of Singapore", Singapore ManagementUniversity,p3:http://www.smu.edu.sg/centres/ises/igcse2009/download/sli des/090723_ProfMarcusLee.pdf (Access Date: 20/08/10, time: 12 pm)

Lalarukh, Farzana, \& Hossain, Zariab, Md. (2008). "A Comparative Study of the PCBS \& NCBS of Bangladesh: A Closer Look into the NCBS", The Cost and Management, P1517.

Oliver, R. L. (1993). "Cognitive, Affective, and Attribute Bases of the Satisfaction Response". Journal of Consumer Research, 20, 418-430.

Pearson, N. (1996). "Building Brands Directly: Creating Business Value from Customer Relationships". Macmillan Business, 20 (6), 68-82.

Parasuraman, A., Zeithaml, V., \& Berry, L. (1988). "SERVQUAL: A multiple Item Scale for Measuring Consumer Perceptions of Service Quality". Journal of Retailing, 6(1), 12-36.

Roest, H., and Pieters, R. (1997). "The Nomological Net of Perceived Service Quality". International Journal of Service Industry Management, 8(4), 336-351.

Spreng, R. A., Harrell, G. D., and Mackoy, R. D. (1995), "Service Recovery: Impact on 
Satisfaction and Intentions", Journal of Services Marketing, 9(1), 201-14.

Sureshchandar, G.S., Chandrasekharan Rajendran and Anantharaman, R.N. (2002), "The

Relationship Between Service Quality and Customer Satisfaction-A Factor Specific Approach", Journal of Services Marketing, 16(4), 363-379.

Wolff, H.K., \& Pant, P.R. (2003). “A Handbook For: Social Science Research and Thesis Writing”. Kathmandu: Budda Academic Publisher and Distributor.

Zeithaml, V. (1987). "Defining and Relating Price, Perceived Quality and Perceived Value". Cambridge, MA: Marketing Science Institute.

Zeithaml, V. A., Parasuraman, A., Berry, L.L. (1990). "Delivering Quality Service:Balancing Customer Perceptions and Expectations", The Free Press, New York: NY.

\section{APPENDIX}

\section{Model Summary}

TABLE 7

\section{REGRESSION ANALYSIS}

\begin{tabular}{c|c|c|c|c}
\hline Model & $\mathrm{R}$ & R Square & Adjusted R Square & Std. Error of the Estimate \\
\hline 1 & $.783(\mathrm{a})$ & .613 & .610 & .50163 \\
\hline
\end{tabular}

Note: a Predictors: (Constant), Opinion regarding the banks service quality in Foreign exchange banking, Opinion regarding the quality of General Banking service. Opinion regarding the banks service quality in credit banking.

TABLE 8

ANOVA TEST

\begin{tabular}{l|cc|c|c|c}
\hline \multicolumn{1}{c|}{ Mode 1 } & $\begin{array}{c}\text { Sum of } \\
\text { Squares }\end{array}$ & df & $\begin{array}{c}\text { Mean } \\
\text { Square }\end{array}$ & F & Sig. \\
\hline Regression & 146.249 & 3 & 48.750 & 193.734 & $.000(\mathrm{a})$ \\
Residual & 92.349 & 367 & .252 & & \\
Total & 238.598 & 370 & & & \\
\hline
\end{tabular}

Note: a. Predictors: (Constant), Opinion regarding the banks service quality in Foreign exchange banking., Opinion regarding the quality of General Banking service. Opinion regarding the banks service quality in credit banking.

b. Dependent Variable: Are you satisfied with the banks performance 
TABLE 9

RESULTS OF MULTIVARIATE (OLS) ANALYSIS

\begin{tabular}{|c|c|c|c|c|c|c|}
\hline \multirow[t]{2}{*}{ Model } & & \multicolumn{2}{|c|}{$\begin{array}{c}\text { Unstandardized } \\
\text { Coefficients }\end{array}$} & \multirow{2}{*}{$\begin{array}{c}\begin{array}{c}\text { Standardized } \\
\text { Coefficients }\end{array} \\
\text { Beta }\end{array}$} & \multirow{2}{*}{ t } & \multirow{2}{*}{$\begin{array}{l}\text { Sig. } \\
\text { Std. } \\
\text { Error }\end{array}$} \\
\hline & & $\mathrm{B}$ & $\begin{array}{c}\text { Std. } \\
\text { Error }\end{array}$ & & & \\
\hline \multirow[t]{4}{*}{1} & (Constant) & -.916 & .144 & -- & -6.371 & .000 \\
\hline & $\begin{array}{l}\text { Opinion regarding the quality } \\
\text { of General Banking service. } \\
\text { This bank is performing well. }\end{array}$ & .527 & .038 & .448 & 13.745 & .000 \\
\hline & $\begin{array}{l}\text { Opinion regarding the banks } \\
\text { service quality in credit } \\
\text { banking. }\end{array}$ & .631 & .044 & .473 & 14.434 & .000 \\
\hline & $\begin{array}{l}\text { Opinion regarding the banks } \\
\text { service quality in Foreign } \\
\text { exchange banking. }\end{array}$ & .376 & .036 & .343 & 10.499 & .000 \\
\hline
\end{tabular}

Note: a. Dependent Variable: Are you satisfied with the banks performance 